\title{
EFFECT OF DIFFERENT PLANT EXTRACTS AND ESSENTIAL OILS ON SOME IMPORTANT FUNGAL PATHOGENS CAUSING DAMPING-OFF AND ROOT ROT DISEASES IN SUGAR BEET.
}

Abdalla, M. E. ; Y. M. Shabana*; A. A. Ismaiel ${ }^{\star \star}$ and I. A. El-Nady ** * Plant Pathology Dept., Fac. Agric., Mansoura University

${ }^{* *}$ Plant Pathology Res. Institute, Agric. Research Center

\begin{abstract}
In this study; we screened seven essential oils and 8 different plant extracts for fungitoxic effect against three soil borne pathogens infect sugar beet. The seven essential oils were from commercial products derived from Camphor, thyme, anise, lettuce; groundnut, rocket and caraway oil and used in 3 concentrations $(0.5,1$ and $2 \% \mathrm{w} / \mathrm{w})$. The eight extracts of higher plant species are belonging to seven different plant families including; Pimpinelle anism, Glycerrhiza glabbra L.; Nigella sativa; Eruca sativa; Eugenia caryophyllus, Artemisia Judaica, Allium cepa and Allium sativum were used to prepare their crude extracts that used in 3 concentrations. 25 , 50 and $75 \% \mathrm{w} / \mathrm{v}$ ). In laboratory; among essential oils, Thyme, Anise and Comphor oils were the most effective, toxic and inhibit mycelial growth of on fugal species. On the contrast, the other essential oils of lettuce, ground nut, rockets and caraway did not cause any toxic effect against all pathogenic fungi under study compared with controls. Among 8 plant extract tested garlic and onion extracts were the most effective and toxic for all fungi tested. The persistence of antifungal activity was different among extracts. All showed decreasing zone of inhibition with time, except Cloves, Artemisia, Onion and Garlic which retained its full activity against the three fungi for the whole incubation period especially at 50 and $75 \%$ concentrations. However, the suppressive effect of other extracts against the other pathogens was either not affected or slightly decreased with time. The highly toxic and promising plant extracts and essential oils of garlic, onion, Artemisia, anise oil, thyme oil were tested in greenhouse and field experiments. In greenhouse and Field experiment, data showed that plant extracts, thyme oil and anise oil were effective in controlling pre-post emergence damping-off and significantly decreased root rot incidence and severity compared with the controls and fungicide. Yield component of total soluble sugars (T.s.s.), sucrose percent in root and sugar purity were increased. All seed treatments with selected plant extracts and oils, significantly increased these yield parameters. Anise oil showed the most significant effect and increase of T,S.S and sucrose percent in roots of sugar plants assayed from plants grown from seed in plots treated with Anise oil in both 2006 and 2007 growing seasons compared with controls and fungicide treatments. Thyme oil and onion extract showed moderate but improved increase in these yield components.

Keywords: Sugarbeet, Soil borne, Fungi; Essential oils, Plant extract.
\end{abstract}

\section{INTRODUCTION}

Sugar beet (Beta vulgaris $\mathrm{L}$ ) is a second important sugar crop after sugar cane in Egypt. Improving its productivity is an urgent demand to meet the sugar consumption of the ever growing population in Egypt. During the last decades, the importance of sugar beets as a basis for sugar industry and as energy plant in developed countries has increased. Soil-borne diseases 
can have a major impact on sugar beet at all stages of its development. In Egypt several investigations have been conducted on the fungi pathogenic to sugar beet (Fahim et al., 1981; E1-Kholi, 1978, 1984; Rizk, 1986; Mosa and Elkholi, 1996; El-Kazzaz et al., 1999; Esh, 2000 and Abada, 1980, 1994 and 2003). Rhizoctonia root and crown rot and other soil born fungal pathogens are causal pathogens of diseases that can have a significant impact on mature sugar beet plants. Rhizoctonia solani Kuhn (teleomorph Thanatephorus cucumeris (Frank) Donk), principally in its AG 2-2 form (Duffus \& Ruppel, 1993). is prevalent in areas with warm climates, e.g., Egypt and it is considered the most serious root disease of sugar beet. In the world, the average losses in USA were $2 \%$, although there is considerable variation, with losses of up to $50 \%$ recorded (Schneider \& Whitney 1986). In Europe, Rhizoctonia is becoming increasingly important with up to $10 \%$ of the sugar beet growing area affected in some countries (Ayala-Garcia et al., 2001 and Luterbacher et al.,2005). Sclerotium rolfsii (teleomorph Athelia rolfsii ; Corticiaceae, Basidiomycota) is a widespread phytopathogenic fungus affecting a large number of agricultural plants (Bateman \& Beer, 1965 and Punja \& Damiani, 1996). In sugar beet, this pathogen can cause several types of damage, including damping-off, crown, and root-rot as well as dry rot canker in older plants (Khettabi et al. 2001; Abada 2003).

Plant oils and extracts have been used for a wide variety of purposes for many thousands of years. Some studies have concentrated exclusively on one oil or one micro-organism. While these data are useful, the reports are not directly comparable due to methodological differences such as choice of plant extract(s), test micro-organism(s) and antimicrobial test method (Janssen et al. 1987 and hammer et al., 1999). In recent years, due to increasing environmental pollution, the need to find alternatives to synthetic chemicals for the control of fungal diseases has been increasingly felt in agriculture. However, increasing concerns with environmental/health effects, pesticide restrictions, and development of fungicide resistance, along with the desire for more sustainable production practices, have enhanced the attractiveness of alternative products for plant disease control. Therefore, the objectives of this study were to: (1) evaluate the effects of natural plant extracts and essential oils in vitro inhibition of $R$. solani, S. rolfsii and $F$. oxysporum in lab assays; and (2) determine the effectiveness of these natural products on the development and suppression of these sugar beet soil born fungal pathogens and plant quality characters in greenhouse and field experiments.

\section{MATERIAL AND METHODS}

\section{Sugar beet pathogenic fungi}

Naturally infected sugar beet plants showing root rot symptoms were collected from several fields at Dakahlia and Sharkia governorates. Isolation of the causal pathogens (Rhizoctonia solani Kuhn , Sclerotium rolfsii Sacc., and Fusarium oxysporum Schlecht. f. sp. betae (Stewart) Snyder and Hansen) were carried out using small pieces of infected roots which were 
previously washed in running tap water, surface sterilized with $1 \%$ sodium hypochlorite solution for two minutes washed three times with sterilized water and dried between sterilized filter papers. The surface sterilized root pieces were then placed into Petri dishes containing PDA medium, then incubated at $20^{\circ} \mathrm{C}$ for seven days. Preliminary identification of the growing fungi were carried out according to (Domsch et al., 1980) and then confirmed by Assiut University Mycological Centre (AUMC) and Plant Pathology Dept., Mansoura University.

Host plant

Seeds of kawmira sugar beet cultivar susceptible to fungal root rot diseases obtained from the North Delta sugar company, Egypt. These were surface sterilized in $5 \%$ sodium hypochlorite for $3 \mathrm{~min}$. then rinsed in sterilized water.

\section{Laboratory experiment:}

The inhibitory effect of essential oil and plant extract on linear growth of pathogenic fungi:

The seven essential oils used were commercial products derived from Camphor, thyme, anise, lettuce; groundnut, rocket and caraway oil obtained from well reputed herbal stores in Egypt. However; the oils were examined and tested and confirmed for genuine and origin in chemistry departments at faculties of Agriculture, Science and Pharmacy at Mansoura University. The seven oils were dissolved in absolute ethyl alcohol and added to PDA immediately before it was emptied into the Petri dishes at a temperature of $40-45^{\circ} \mathrm{C}$ and tested in concentrations of $0.5,1$ and $2 \%(\mathrm{v} / \mathrm{v})$. A final concentration of $1 \%(\mathrm{v} / \mathrm{v})$ Tween-20 (Sigma) was incorporated into the agar medium after autoclaving to enhance oil solubility. The controls received the same quantity of ethyl alcohol mixed with PDA- $1 \%$ Tween medium.

Eight extracts of higher plant species belonging to seven different plant families including; Pimpinelle anism, Glycerrhiza glabbra L.; Nigella sativa; Eruca sativa; Eugenia caryophyllus, Artemisia Judaica, Allium cepa and Allium sativum were used to prepare their crude extracts. Weights (g) of seeds, leaves or bulbs depend on each plant species were used to prepare the crude extract equivalent to $0,25,50$, and $75 \%(\mathrm{v} / \mathrm{v})$ per liter concentrations. Leaves were chopped; seeds or bulbs were crushed and mixed in molten PAD to provide these concentrations. Afterwards; they were mixed together in a blender for $1 \mathrm{~min}$ before dextrose and agar were added (20 and $18 \mathrm{~g} / \mathrm{l}$; respectively) and an autoclave process was carried out for 20 min at $120^{\circ} \mathrm{C}$. Each crude extract was sieved with sterilized cheese cloth fixed on the mouth of the PDA container then directly poured or dispensed to $9 \mathrm{~cm}$ Petri dishes (5 replicates per concentration). In control treatments only PDA medium was used. The pathogenic fungi of ( $R$. solani, $F$. oxysporum and Sclerotium rolfsii) were inoculated immediately after preparation of the Petri dishes by placing a disk of mycelial growth $(0.5 \mathrm{~cm}$ diameter $)$, in the centre, taken from the rim of 7-day-old cultures on PDA plates. The Petri dishes were kept wrapped in aluminum foil at a temperature of $22^{\circ} \mathrm{C}$. The inspections were made after $3,5,7$ and 10 days, measuring the growth of the fungal colonies along two preset diametric lines when the complete growth of fungi in control plates reaches to maximum growth $(\geq 9 \mathrm{~cm})$. All tests were 
repeated five times. Fungitoxicity was expressed in terms of percentage of mycelial growth inhibition and calculated according to the formula of Pandey et al. (1982):

\{dc - dt / dc X 100\};

Where $\mathbf{d c}=$ average diameter of fungal colony with control; $\mathbf{d t}=$ average diameter of fungal colony with treatment.

\section{Greenhouse experiment}

Effect of seed treatment with effective plant extracts and essential oils.

Pure fungal cultures of $R$. solani, $F$. oxysporum and $S$. rolfsii were tested for their pathogenic capabilities. Inocula of the isolated fungi were prepared in weak PDA medium (half strength of ingredients), and inoculated with mycelial disks from a five days old culture of pathogens and incubated for 14 days at $20^{\circ} \mathrm{C}$, then suspended in sterile water and homogenized in a blender for $5 \mathrm{~min}$. Earthen pots (50 $\mathrm{cm}$-diameter) filled with loamy sand soil ( $84 \%$ sand : $14.5 \%$ clay : $1.5 \%$ silt) were used. Soil infestation was carried out 7 days before sowing by adding ten $\mathrm{ml}$ of the homogenized culture containing $5 \times 106 / \mathrm{ml}$ of fungal propagules of $F$. oxysporum while Cultures of $R$. solani and S. rolfsii from five Petri dishes were macerated in $200 \mathrm{ml}$ distilled water; diluted to I liter of sterilized water and $10 \mathrm{ml}$ of the homogenized cultures mixed with the top $5 \mathrm{~cm}$ of the pot soil and mixed thoroughly. Each pot was filled with $3 \mathrm{~kg}$ sterilized autoclaved soil. Five pots were used for each tested fungal isolate. Different oils and plant extracts, which showed high reduction of mycelial growth of pathogenic fungi in laboratory assays, were used for greenhouse experiments. Kawmira cultivar seeds were disinfected with $2 \%$ sodium hypochlorite solution for two minutes then dried and soaked overnight in oil and plant extracts concentration resulted in higher inhibition of fungi in Petri dishes. The treated seeds were air-dried and ten seeds were sown in the rate of 10 seeds/pot. Irrigation was performed when necessary. The percentage of pre- and post-emergence damping-off was calculated after 15 and 30 days, respectively. Uninoculated soil was served as control. Five pots were used for each particular treatment. Seed soaked in sterilized water were sown in the same method as a control. Re-isolation of the pathogenic fungal isolates from diseased plants was carried out to meet Koch postulates.

\section{Field experiments:}

Field experiment were conducted in randomized complete block design with 4 replicates under natural infected fields during 2006 and 2007 winter growing seasons to study the effect of selected essential oils and plant extracts on natural infection occurred with damping-off after 15 and 45 days of planting time. Seeds of Kawmira cultivar susceptible to soil borne pathogens under study were soaked overnight in selected promising plant extracts and essential oils that showed toxic and inhibition to the fungi species under laboratory experiments. Concentration of plant extracts (Garlic, Onion and Artemesia) was $75 \%$ and $1 \%$ for Anise and Thyme essential oils. Sugar beet was harvested by hand and assessed for disease symptoms. 
Disease incidence and disease severity were determined at harvest time after 180 days of planting time.

For rating disease symptoms on the roots, two different scales were used, Ruppel's scale (Ruppel et al. 1979) which consists of seven disease classes. This scale were based on the percentage of rotten root surface. Disease index (D1, $0 \leq$ D1 $\leq 7$ ) was calculated according to Ruppel's formula (Ruppel et al. 1979) as:

\section{DI $=\underline{\Sigma(D i s e a s e ~ c l a s s ~} \mathrm{x}$ number of plants within that class)} Total number of plants within plot.

In addition, some yield component parameters i.e., total soluble solids (TSS), sucrose (\%) and sugar purity were also estimated. TSS was estimated in fresh roots using the hand refractometer according to McGinnis (1982). Sucrose percent was estimated according to A.O.A.C. (1990) by adding $173 \mathrm{ml} 3 \%$ lead acetate to $26 \mathrm{~g}$ from sample representing the interior of the roots. After filtration, sucrose percent was measured by the aid of saccarometer. Purity percent was calculated by dividing the sucrose percent by TSS.

\section{Statistical analysis:}

All the obtained results were statistically analyzed according to Gomez and Gomez 1984.

\section{RESULTS}

\section{Effect of plant extracts on linear growth of pathogenic fungi:}

Results in Table (1) showed that plant extracts differed in their reaction against pathogenic fungi. Certain extracts stimulated, others showed moderate inhibition and some were highly toxic to one or more fungi species. Garlic, Onion, Clove and Artemisia extracts were the most toxic and showed completely inhibited mycelial growth of S.rolfsii at $75 \%$ concentration. Clove extract was highly toxic and showed complete inhibition of $R$. solani at $50 \%$ conc. and $F$. oxysporum at $75 \%$ con. Garlic showed higher inhibition $(85.92 \%)$ of $R$. solani growth and $86.66 \%$ of $F$. oxysporum growth. Onion extract showed $69.25 \%$ reduction of $R$. solani and $65.55 \%$ of $F$. oxysporum growth followed by Artemisia extract. Nigella, Anise, liquarice extracts as well as Rocket seeds extracts had slight effect on mycelial growth inhibition. Therefore, this promising plant extracts of garlic, onion and Artemisia were further studied greenhouse and field experiments. The persistence of antifungal activity was different among extracts. All showed decreasing zone of inhibition with time, except Cloves, Artemisia, Onion and Garlic which retained its full activity against the three fungi for the whole incubation period especially at 50 and $75 \%$ concentrations. However, the suppressive effect of other extracts against the other pathogens was either not affected or slightly decreased with time. 
Table (1): Effect of plant extracts from eight different plant species on linear growth of Rhizoctonia solani, Fusarium oxysporum and Sclerotium rolfsii isolated from infected sugar beet root

\begin{tabular}{|c|c|c|c|c|c|c|c|}
\hline \multirow{3}{*}{ Plant extracts c } & \multirow{3}{*}{$\begin{array}{c}\text { Conc. } \\
\text { (\%) } \\
\text { v/w }\end{array}$} & \multicolumn{6}{|c|}{ Fungal species } \\
\hline & & \multicolumn{2}{|c|}{ R. solani } & \multicolumn{2}{|c|}{ F. oxysporum } & \multicolumn{2}{|c|}{ S. rolfsii } \\
\hline & & L.G $\mathbf{G}^{\mathbf{a}}$ & $\begin{array}{c}\% \\
\text { Inhibition }{ }^{b}\end{array}$ & L.G & $\begin{array}{c}\% \\
\text { inhibition }\end{array}$ & L.G & $\begin{array}{c}\% \\
\text { inhibition }\end{array}$ \\
\hline Control & 0 & $\geq 9.00^{b}$ & 0.00 & $\geq 9.00$ & 0.0 & $\geq 9.00$ & 0.0 \\
\hline \multirow{3}{*}{$\begin{array}{l}\text { Nigella Sativa } \\
\text { (Nigella) }\end{array}$} & 25 & 7.26 & 22.94 & 7.03 & 21.84 & 9.00 & 0.0 \\
\hline & 50 & 4.53 & 45.18 & $4.63^{*}$ & 48.51 & 6.76 & 26.29 \\
\hline & 75 & 3.93 & 56.29 & $4.46^{*}$ & 50.36 & $3.33^{\star *}$ & 62.96 \\
\hline \multirow{3}{*}{$\begin{array}{l}\text { Eruca Sativa } \\
\text { ( Rocket) }\end{array}$} & 25 & 9.00 & 0.00 & 6.03 & 32.95 & 9.00 & 0.0 \\
\hline & 50 & 5.90 & 38.14 & 5.30 & 41.11 & 9.00 & 0.0 \\
\hline & 75 & $4.56^{*}$ & 49.25 & 5.00 & 48.14 & 6.40 & 28.51 \\
\hline \multirow{3}{*}{$\begin{array}{l}\text { Engenea caryophylus } \\
\text { (Cloves) }\end{array}$} & 25 & 2.53 & 71.85 & $3.60^{* *}$ & 59.99 & 6.30 & 29.29 \\
\hline & 50 & $0.00^{* *}$ & 100 & $2.90^{\star *}$ & 67.77 & $0.00^{\star \star}$ & 100 \\
\hline & 75 & $0.00^{* *}$ & 100 & $0.00^{* *}$ & 100 & $0.00^{\star *}$ & 0.0 \\
\hline \multirow{3}{*}{$\begin{array}{l}\text { Artemisia Judaica } \\
\text { (Artemesia) }\end{array}$} & 25 & 9.00 & 0.00 & 6.43 & 28.51 & 6.53 & 27.40 \\
\hline & 50 & 4.83 & 44.07 & 5.30 & 37.40 & $2.5^{*}$ & 72.22 \\
\hline & 75 & $3.86^{*}$ & 57.03 & $4.70^{*}$ & 47.77 & $0.00^{\star \star}$ & 100 \\
\hline \multirow{3}{*}{$\begin{array}{l}\text { Glycyrrhira glabra } \\
\text { ( Liquuarice) }\end{array}$} & 25 & 7.80 & 13.33 & 7.57 & 15.92 & 6.43 & 28.51 \\
\hline & 50 & 5.50 & 38.88 & 6.86 & 23.7 & 5.53 & 38.51 \\
\hline & 75 & 4.40 & 51.11 & 6.10 & 32.22 & $0.00^{\star *}$ & 100 \\
\hline \multirow{3}{*}{$\begin{array}{l}\text { Allium Cepa } \\
\text { (Onion) }\end{array}$} & 25 & 3.70 & 58.88 & $3.93^{\star *}$ & 56.29 & $2.80^{*}$ & 68.14 \\
\hline & 50 & $2.7^{\star *}$ & 69.99 & $2.67^{\star \star}$ & 70.36 & $0.0^{* *}$ & 100 \\
\hline & 75 & $1.27^{*}$ & 85.92 & $1.20^{\star *}$ & 86.66 & $0.0^{* *}$ & 100 \\
\hline \multirow{3}{*}{$\begin{array}{l}\text { Pimpinella anism } \\
\text { (Anise) }\end{array}$} & 25 & 8.10 & 9.99 & 7.70 & 14.44 & 9.00 & 0.0 \\
\hline & 50 & 7.10 & 20.73 & 6.60 & 26.67 & $4.10^{*}$ & 54.44 \\
\hline & 75 & 6.00 & 39.99 & 5.70 & 37.03 & $0.60^{\star \star}$ & 93.70 \\
\hline \multirow{3}{*}{$\begin{array}{l}\text { Allium Sativum } \\
\text { (Garlic) }\end{array}$} & 25 & 7.10 & 20.36 & 6.30 & 29.62 & $2.30^{*}$ & 74.44 \\
\hline & 50 & $4.10^{*}$ & 53.70 & 5.03 & 47.77 & $0.00^{\star *}$ & 100 \\
\hline & 75 & $2.76^{\star \star}$ & 69.25 & $3.10^{\star \star}$ & 65.55 & $0.00^{\star \star}$ & 100 \\
\hline \multirow{2}{*}{ L.S.D } & $(0.05)^{*}$ & 0.41 & - & 0.50 & - & 0.46 & - \\
\hline & $(0.01)^{* *}$ & 0.55 & - & 0.67 & - & 0.61 & - \\
\hline
\end{tabular}

a Control plates with ethyl and tween only, diameters measures started when the complete growth of fungi reaches to maximum growth ( $\geq 9 \mathrm{~cm}$ ). L.G. = linear growth was expressed in terms of percentage of mycelial growth inhibition and calculated according to the formula of Pandey et al. (1982). \{dc - dt / dc X 100\};; Where dc = average diameter of fungal colony with control; $\mathrm{dt}=$ average diameter of fungal colony with treatment. Inhibition $\%=$ percent reduction in culture growth compared to growth measure in control plates (fungi grow on PDA plates without plant extract . ${ }^{c}$ Scientific name of plant followed by English name between brackets.

\section{Effect of essential oils on linear growth of pathogenic fungi:}

Data in Table (2) showed the toxic effects of 7 commercial oils against R.solani, F.oxysporum and $S$.rolfsii at three concentration $(0.5,1$ and $2 \%)$. Certain oils stimulated, others showed moderate inhibition and some were highly toxic to one or more fungi species. The complete inhibition in linear growth obtained by Thyme, Anise and Comphor oils on S.rolfsii. Thyme and Anise oils were highly toxic to R.solani and F.oxysporum and inhibited their mycelium growth completely $1 \%$ conc. On the contrast, the other essential oils of lettuce, ground nut, rockets and caraway did not cause any toxic effect against all pathogenic fungi under study compared with controls. 
Table (2): Effect of essential oils on linear growth of Rhizoctonia solani, Fusarium oxysporum and Sclerotium rolfsii isolated from infected sugar beet root

\begin{tabular}{|c|c|c|c|c|c|c|c|}
\hline \multirow[b]{3}{*}{ Essential oils } & \multirow[b]{3}{*}{$\begin{array}{c}\text { Conc. } \\
(\%) \\
\text { v/v }\end{array}$} & \multicolumn{6}{|c|}{ Fungal species } \\
\hline & & \multicolumn{2}{|c|}{ R. Solani } & \multicolumn{2}{|c|}{ F. oxysporum } & \multicolumn{2}{|c|}{ S. rolfsii } \\
\hline & & L.G ${ }^{a}$ & $\begin{array}{c}\% \\
\text { Inhibition } \mathrm{b}\end{array}$ & L.G & $\begin{array}{c}\% \\
\text { inhibition }\end{array}$ & L.G & $\begin{array}{c}\% \\
\text { inhibition }\end{array}$ \\
\hline 0. Control & 0 & $\geq 9.00^{b}$ & 0.0 & $\geq 9.00$ & 0.0 & $\geq 9.00$ & 0.0 \\
\hline \multirow{3}{*}{ 1. Camphor } & 0.5 & 9.0 & 0.0 & 9.0 & 0.0 & 5.9 & 33.69 \\
\hline & 1 & 9.0 & 0.0 & $5.8^{*}$ & 35.55 & $0.0^{\star \star}$ & 100 \\
\hline & 2 & $3.4^{\star \star}$ & 62.22 & $4.7^{*}$ & 41.11 & $0.0^{* \star}$ & 100 \\
\hline \multirow{3}{*}{ 2. Thyme } & 0.5 & 5.7 & 37.03 & 4.46 & 50.36 & $2.76^{\star *}$ & 69.25 \\
\hline & 1 & $0.0^{\star \star}$ & 100 & $1.4^{\star \star}$ & 84.07 & $1.2^{\star \star}$ & 86.66 \\
\hline & 2 & $0.0^{\star *}$ & 100 & $0.0^{* *}$ & 100 & $0.0^{* *}$ & 100 \\
\hline \multirow{3}{*}{ 3. Anise } & 0.5 & $0.8^{\star \star}$ & 91.10 & $4.9^{*}$ & 45.56 & $1.1^{* *}$ & 87.77 \\
\hline & 1 & $0.0^{\star \star}$ & 100 & $0.0^{* *}$ & 100 & $0.0^{* \star}$ & 100 \\
\hline & 2 & $0.0^{\star \star}$ & 100 & $0.0^{\star *}$ & 100 & $0.0^{* *}$ & 100 \\
\hline \multirow{3}{*}{ 4. Lettuce } & 0.5 & 9.0 & 0.0 & 9.0 & 0.0 & 9.0 & 0.0 \\
\hline & 1 & 9.0 & 0.0 & 9.0 & 0.0 & 9.0 & 0.0 \\
\hline & 2 & 9.0 & 0.0 & 9.0 & 0.0 & 9.0 & 0.0 \\
\hline \multirow{3}{*}{ 5. Ground nut } & 0.5 & 9.0 & 0.0 & 9.0 & 0.0 & 9.0 & 0.0 \\
\hline & 1 & 9.0 & 0.0 & 9.0 & 0.0 & 9.0 & 0.0 \\
\hline & 2 & 9.0 & 0.0 & 9.0 & 0.0 & 9.0 & 0.0 \\
\hline \multirow{3}{*}{ 6. Rocket } & 0.5 & 9.0 & 0.0 & 9.0 & 0.0 & 9.0 & 0.0 \\
\hline & 1 & 9.0 & 0.0 & 9.0 & 0.0 & 9.0 & 0.0 \\
\hline & 2 & 9.0 & 0.0 & 9.0 & 0.0 & 9.0 & 0.0 \\
\hline \multirow{3}{*}{ 7. Caraway } & 0.5 & 9.0 & 0.0 & 9.0 & 0.0 & 9.0 & 0.0 \\
\hline & 1 & 9.0 & 0.0 & 9.0 & 0.0 & 9.0 & 0.0 \\
\hline & 2 & 9.0 & 0.0 & 9.0 & 0.0 & 9.0 & 0.0 \\
\hline \multirow[t]{2}{*}{ L.S.D } & $(0.05)^{*}$ & 0.42 & - & 0.49 & - & 0.57 & - \\
\hline & $(0.01)^{\star \star}$ & 0.56 & $=$ & 0.65 & - & 0.77 & \\
\hline
\end{tabular}

${ }^{a}$ Control plates (PDA only), measures of cultures diameters started when the complete growth of fungi reaches to maximum growth $(\geq 9 \mathrm{~cm})$. L.G. = linear growth was expressed in terms of percentage of mycelial growth inhibition and calculated according to the formula of Pandey et al. (1982). \{dc $-\mathrm{dt} / \mathrm{dc} \times 100\}$; Where dc = average diameter of fungal colony with control; $\mathrm{dt}=$ average diameter of fungal colony with treatment.

${ }^{b}$ Inhibition $\%=$ percent reduction in culture growth compared to growth measure in control plates (fungi grow on PDA plates without plant extract .

\section{Greenhouse experiment}

Data presented in Fig.(a, b and c) revealed variation in the antifungal properties of the selected essential oils and plant extracts compared with control and fungicide treatments.

For symptoms caused by artificial infestation of soil with $R$. solani. Data presented in Fig. (1-a) showed that highest reduction in pre-, postemergence damping off and root rot in the early and late stages of seedling growth was attributed to Anise, Thyme oils followed by Onion and Garlic extracts. This was expressed in higher percentage of survival plants $(78,62$, 58 and $48 \%$ ) due to seed treatments with these oils and extracts, respectively compared with control ( $28 \%$ ) and fungicide treatment $(72 \%)$. The lowest disease incidence was $10 \%$ in treatments of seeds soaked in Anise and Thyme oils followed by Garlic and Onion extracts (20\%). Artemisia extract 
showed a moderate reduction of damping off and root rot symptoms but it was significant compared with control. However, disease severity (DS\%) in all treatments was significantly reduced compared with control.

Pots infested with $F$. oxysporum showed variable effects on pre and post-emergence damping off. Data presented in Fig. (1-b) showed high significant reduction of pre and post damping off symptoms Anise (14\%) and Thyme (16-18\%) oils followed by treatments of Garlic (18-22\%) and Onion (22-26\%) extracts. The Artemesia extract has no significant effect (24-30\%) compared with control treatment. Root rot incidence and severity were significantly reduced in all treatments except Artemesia extract compared with control.

The results obtained and presented in Fig. (1-c) showed that diseases symptoms caused by $S$. rolfsii were significantly reduced in all treatment except treatment of seeds soaked in Artemesia extract. However, Artmessia caused significant reduction of post-emergence damping off. The higher percentages of healthy survived seedlings were found in treatments of seeds soaked in Anise (70\%) and Thyme (66\%) oils followed by Garlic (56\%) and onion (54\%) extracts compared with control treatment.

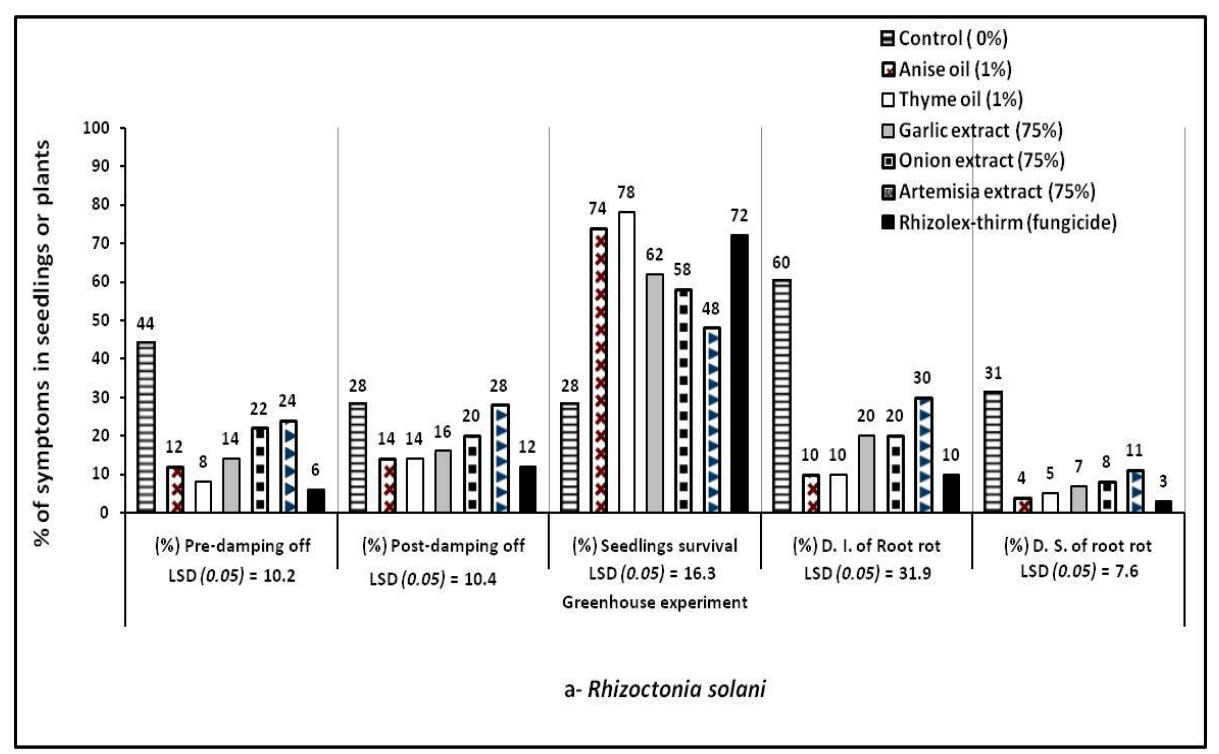



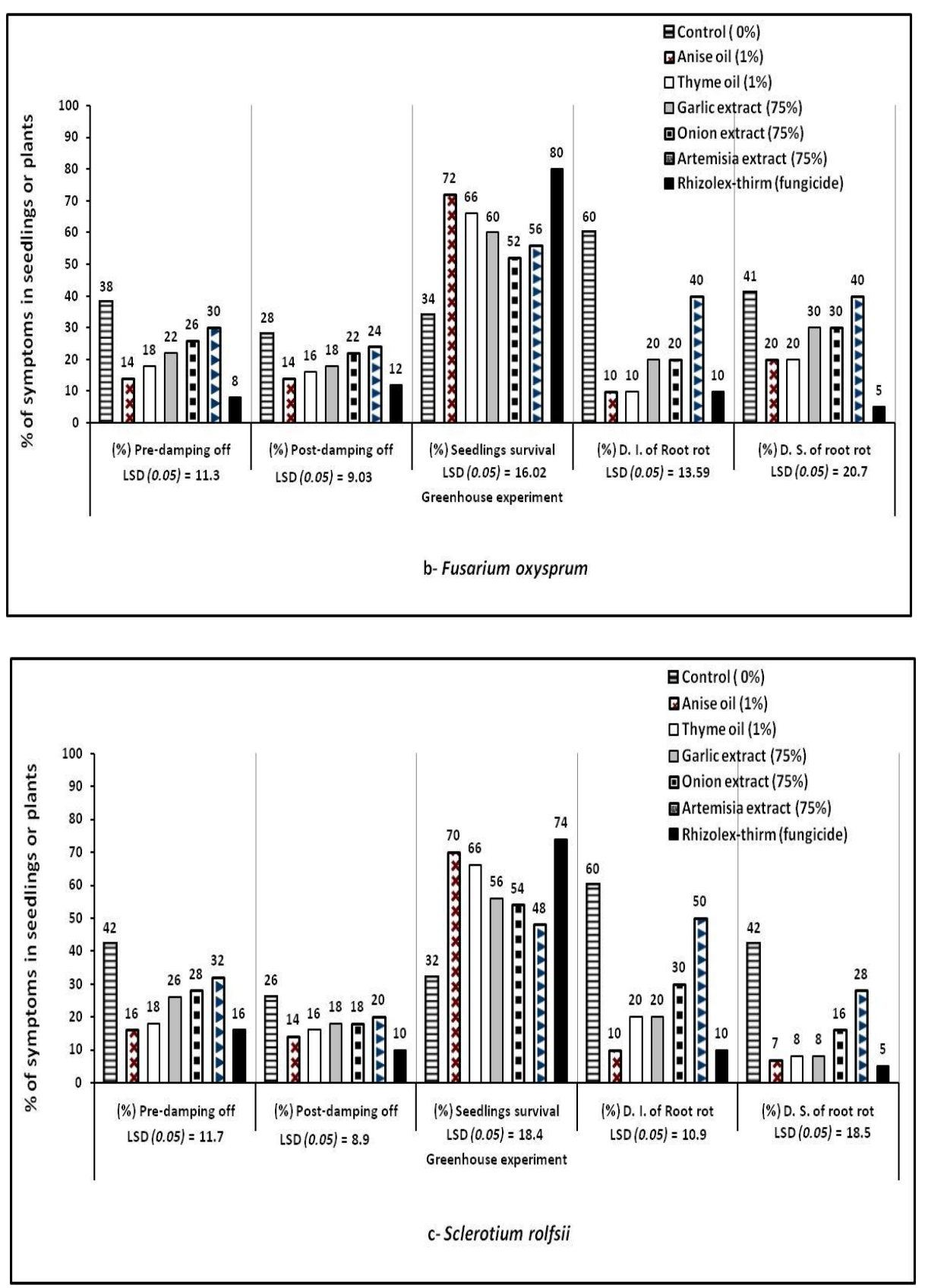

Fig. 1. Effect of some effective essential oil and plant extracts used in treatment of sugar beet seeds to control damping off and root rot diseases caused by (a) Rhizoctonia solani, (b) Fusarium oxysporum and (c) Sclerotium rolfsii in greenhouse experiments. 
Field experiment

Data presented in Table 3 revealed toxic effect in the antifungal properties of the selected essential oils and plant extracts compared with control and fungicide treatments. Sugar beet plants naturally infected under field condition were examined in early seedling stage and late at mature root or harvest stage. In early stage, all plant extracts and essential oils used in seed treatment showed highly significant reduction ( $P=0.01$ and 0.05$)$. Anise and Thyme oils were the most effective seed treatment against diseases caused by soil borne fungi under investigation both in early stage and at harvest expressed as lower percentages of disease incidence $(2.66,3 \%$ and $2,3 \% \%)$ and disease severity $(1.5,3 \%$ and $1.3,2 \%)$ compared with controls in both seasons 2006 and 2007 of the experiments, respectively. Plant extracts of Garlic, onion and Artemesia a moderate but significant reduction of damping off and root rot symptoms compared with plants in the plots of the control treatments in booth 2006 and 2007 seasons.

Table (3): Effect of sugar beet seed treatment with selected essential oil and plants extracts on seedling damping-off and root rot diseases of sugar beet plant under field condition

\begin{tabular}{|c|c|c|c|c|c|c|}
\hline \multirow[b]{2}{*}{$\begin{array}{l}\text { Treatment } \\
\text { (Conc. \%) }\end{array}$} & \multicolumn{3}{|c|}{ First season 2006 trial } & \multicolumn{3}{|c|}{ Second season 2007 trial } \\
\hline & $\begin{array}{c}\text { Damping- } \\
\text { off } \\
(\%)\end{array}$ & $\begin{array}{c}\text { Disease } \\
\text { incidence } \\
(\%)^{c}\end{array}$ & $\begin{array}{c}\text { Disease } \\
\text { severity } \\
(\%)\end{array}$ & $\begin{array}{c}\text { Damping- } \\
\text { off } \\
(\%)\end{array}$ & $\begin{array}{c}\text { Disease } \\
\text { incidence } \\
(\%)\end{array}$ & $\begin{array}{c}\text { Disease } \\
\text { severity } \\
(\%)\end{array}$ \\
\hline $\begin{array}{l}\text { Garlic extract } \\
(75 \%)^{\text {b }}\end{array}$ & $6.67^{\star a}$ & $3.66^{\star *}$ & $2.40^{* *}$ & $4.50^{* *}$ & $3.33^{* *}$ & $2.50^{\star \star}$ \\
\hline $\begin{array}{l}\text { Onion extract } \\
(75 \%)\end{array}$ & $8.89^{*}$ & $4.33^{\star *}$ & $3.23^{* *}$ & $6.67^{* *}$ & $4.66^{* *}$ & $3.83^{\star *}$ \\
\hline $\begin{array}{l}\text { Artemisia extract } \\
(75 \%)\end{array}$ & 11.1 & $5.66^{\star *}$ & $3.83^{\star *}$ & $8.89^{* *}$ & $6.33^{* *}$ & $4.33^{\star *}$ \\
\hline $\begin{array}{l}\text { Anise oil } \\
(1 \%)\end{array}$ & $3.54^{* *}$ & $2.66^{\star *}$ & $1.50^{* *}$ & $4.44^{\star *}$ & $2.00^{* *}$ & $1.33^{\star *}$ \\
\hline $\begin{array}{l}\text { Thyme oil } \\
(1 \%)\end{array}$ & $4.44^{* *}$ & $3.00^{* *}$ & $3.06^{* *}$ & $6.67^{* *}$ & $3.00^{* *}$ & $2.10^{\star *}$ \\
\hline $\begin{array}{l}\text { Rhizolex-Thiram } \\
(3 \mathrm{~g} / \mathrm{kg})\end{array}$ & $3.24^{* *}$ & $0.66^{\star *}$ & $0.26^{\star *}$ & $2.22^{\star \star}$ & $1.33^{\star *}$ & $0.53^{\star \star}$ \\
\hline Control & 15.5 & 20.33 & 40.33 & 17.08 & 19.66 & 20.50 \\
\hline $\begin{array}{ll}\text { L.S.D } & (0.05 \%)^{* d} \\
\end{array}$ & 5.37 & 6.06 & 1.50 & 2.02 & 1.29 & 1.53 \\
\hline L.S.D $(0.01 \%)^{* *}$ & 7.27 & 8.19 & 2.02 & 2.74 & 1.74 & 2.06 \\
\hline
\end{tabular}

${ }^{a}$ values are means of four replicates values. ${ }^{b}$ Susceptible cultivar ( Kuamira was used in these trials. Selected promising plant extracts and essential oils that showed toxic to the fungi species under laboratory experiments. Concentration of plant extracts (Garlic Onion and Artemesia) was $75 \%$ and $1 \%$ for Anise and Thyme essential oils. ${ }^{c}$ Disease incidence and disease severity were determined at harvest time after 180 days of planting time. For rating disease symptoms on the roots, Ruppel's scale was used (Ruppel et al. 1979). ${ }^{d}$ Least significant difference at $P(0.01 \& 0.05)$

\section{Effect of seed treatment on sucrose, total soluble solids and purity}

Effect of different treatments on yield components juice quality parameters are total soluble solids percentage (T.S.S \% ), sucrose percentage and purity percentage. These parameters are widely affected by internal and external factors. The results obtained in Table (4) showed that T.S.S\% and sucrose \% positively affected by all seed treatments. Anise oil 
showed the most significant effect and increase of T,S.S and sucrose percent in roots of sugar plants assayed from plants grown from seed in plots treated with Anise oil in both 2006 and 2007 growing seasons compared with controls and fungicide treatments. Thyme oil and onion extract showed moderate but improved increase in these yield components. As shown in Table 4, the more sucrose percentage occurred, the more purity of sugar extraction happened.

Table (4) Effect of some plant extracts and essential oils used to control seedling damping-off and root rot diseases on some yield parameters of sucrose content, total soluble solids (T.s.s.) and purity percentage of sugar beet roots .

\begin{tabular}{|c|c|c|c|c|c|c|}
\hline \multirow[b]{2}{*}{ Treatments } & \multicolumn{3}{|c|}{$\begin{array}{c}\text { First season } 2006 \\
\text { trial }\end{array}$} & \multicolumn{3}{|c|}{ Second season 2007 trial } \\
\hline & Sucrose $^{a}$ & T.s.s & Purity & Sucrose & T.s.s & Purity \\
\hline $\begin{array}{l}\text { Garlic extract } \\
(75 \%)^{\text {b }}\end{array}$ & $18.98^{*} \mathrm{~b}$ & $22.15^{\star *}$ & 85.98 & $18.42^{*}$ & $22.53^{*}$ & $84.73^{*}$ \\
\hline $\begin{array}{l}\text { Onion extract } \\
(75 \%)\end{array}$ & $19.23^{*}$ & 21.73 & $88.49^{*}$ & $19.65^{\star}$ & 21.82 & $90.14^{\star *}$ \\
\hline $\begin{array}{l}\text { Artemisia extract } \\
(75 \%)\end{array}$ & $17.32^{*}$ & 21.76 & 79.54 & $17.53^{*}$ & $22.59^{*}$ & $77.62^{*}$ \\
\hline $\begin{array}{l}\text { Anise oil } \\
(1 \%)\end{array}$ & $20.18^{\star *}$ & $23.05^{\star *}$ & $89.07^{\star}$ & $19.99^{\star *}$ & $23.05^{*}$ & $90.67^{* *}$ \\
\hline $\begin{array}{l}\text { Thyme oil } \\
(1 \%)\end{array}$ & $19.19^{*}$ & 21.88 & $87.52^{*}$ & $19.51^{*}$ & $22.33^{*}$ & $87.47^{\star}$ \\
\hline $\begin{array}{l}\text { Rhizolex-Thiram } \\
(3 \mathrm{~g} / \mathrm{kg})\end{array}$ & $20.08^{\star *}$ & $21.99^{*}$ & $92.24^{* *}$ & $19.98^{*}$ & 21.99 & $92.26^{\star \star}$ \\
\hline Control & 13.51 & 19.06 & 65.17 & 11.77 & 17.98 & 62.84 \\
\hline $\begin{array}{ll}\text { L.S.D } & (0.05 \%)^{* d} \\
\end{array}$ & 1.88 & 2.007 & 7.85 & 2.09 & 2.88 & 2.11 \\
\hline
\end{tabular}

a Yield component parameters of; Total soluble solids (TSS) was estimated in fresh roots using the hand refractometer according to McGinnis (1982); Sucrose percent was estimated according to A.O.A.C. (1990) and Purity percent was calculated by dividing the sucrose percent by TSS. ${ }^{b}$ Values are means of four replicates values.

c Susceptible cultivar ( Kuamira was used in these trials. Selected promising plant extracts and essential oils that showed toxic to the fungi species under laboratory experiments. Concentration of plant extracts (Garlic, Onion and Artemesia) was $75 \%$ and $1 \%$ for Anise and Thyme essential oils. ${ }^{d}$ Least significant difference at $P(0.01$ \& 0.05)

\section{DISCUSSION}

Fungicides are currently the only commercially available practices for controlling rust disease of sugar beet. The need of reducing fungicide residues in food crops, as concerned for a healthy environment; some of sugar beet cultivars are used for their good crop and sugar yield irrespective of their susceptibility and often, the unavailability of commercially acceptable resistant cultivars emphasize the need for alternative methods for disease control. One of the potential methods is the use of a number of compounds that have not direct antimicrobial activity but increase resistance or at least decrease symptoms, in some host-pathogen interactions (Kessmann et al., 1994 and Ata et al., 2008). Besides biological and genetic engineering 
techniques, natural substances are also being used which appear to have fungicidal properties. Literature provides examples of essential oils that have inhibited the development of fungi, in vitro and in the field. In particular, good results have been obtained with thyme oil (Maruzzela and Baiter, 1959; Arras and Picci, 1984; Carta and Arras, 1987; Brunelli et al., 1990) and mint oil (Maiti et al., 1985). However; less is known about the effects of these substances on fungal mycelium. In this regard; natural products from plant oils and extracts have shown some bioactivity on $P$. infestans (Quintanilla et al. 2002) and on other plant pests and diseases (Isman 2000). Also, it has been reported to reduce the growth of fungal and bacterial pathogens such as Botrytis cinerea, Fusarium spp., and Clavibacter michiganensis (Daferera et al. 2003). In the present study; we screened seven essential oils from commercial products derived from Camphor, thyme, anise, lettuce; groundnut, rocket and caraway oil. Also, eight extracts of higher plant species belonging to seven different plant families including; Pimpinelle anism, Glycerrhiza glabbra L.; Nigella sativa; Eruca sativa; Eugenia caryophyllus, Artemisia Judaica, Allium cepa and A. sativum were used to prepare their crude extracts. Plant extracts and their constituents in some species are known to have antifungal properties. Among 8 plant extract tested; $A$. sativum was the most effective toxic for all fungi tested and suppressed mycelium linear growth of all tested fungi to $65.5 \%-100 \%$. These results agree with many workers who reported the antifungal activity of garlic extract against these fungi (El-Shami et al., 1995; Carcia and Lawas, 1990). The high antifungal activity of garlic extract possibly due to some sulfer containing compounds alliin [(+) -s- allyl -L- Cystine sulphoxide]. Alliin is hydrolyzed to sulfenate, pyruvate and ammonia by alliinase enzymeof sulfenate and it gives allicin which identified and as antifungal by many researcher. Garlic extract also contain antifungal ajoene [(E, Z)- 4, 5, 9-tri - thiadodeca- 196,11- triene9- oxide]. These reported by many researchers (Lawson et al., 1991).

Onion caused complete inhibition of $S$. rolfsii to $50 \%$ and $85 \%$ inhibition of $F$. oxysporum and $R$. solani at $75 \%$ conc.. We noticed that some plant extracts had slight or no effect on the myceilal growth on the tested fungi. Pimpinella anism extract caused moderate reduction in the linear growth of R.solani and F.oxysporum, but it strongly inhibited linear growth of S. rolfsii $(93-75 \%)$.

The aqueous extract of Glycyrrhiza glabra highly reduced the linear growth of $S$. rolfsii by $100 \%$ at $75 \%$ conc. and only by $51-32 \%$ on $R$. solani and F. oxysporum, respectively. Artemisia judiaca caused complete inhibition of $S$. rolfsii, but showed moderate reduction in other fungi as well as other extracts. The above mentioned results indicated that the tested plant extracts differed in their reaction against fungi. The differences might be due to the concentration of active ingredient and the presence of antifungal or growth stimulant like substances in plant material. These results agree with those reported by (Agha, 1992; Zeidan 1993). The efficiency of soaking seeds in garlic and onion and Artemisia plant extracts in controlling sugar beet root-rot disease caused by $R$. solani, $F$. oxysporum and S. rolfsii was studied under pot experiment. Garlic cloves extract proved to be the most effective antifungal substances when used as seed soaking before soaking, followed 
by onion extract. In this regard, Artemisia extract had the lowest effect. These effects might be due to the absorption and translocation of active substance into seeds or seedling tissue and remain of inactive during the seedling stage. The stimulatory effect of some extracts to certain fungi may be due to the presence of growth promoting substances or nutritive material in the extracts to the fungi. This effect could be of significance for growing the fungus in vitro. The stimulatory effect of extracts at low concentration and their inhibitory effect at high concentration is a typical character of certain pesticides (Fedtke, 1982), Some plant extracts have been reported to stimulate growth of one or more plant pathogens (Shekhawat and Prasada, 1971; Rizki et al,, 1984).

In field experiment, data showed that three tested and promising plant extracts were generally effective in controlling pre-post emergence dampingoff and significantly decreased the root rot incidence compared with the control. Among extracts, Garlic extract was considered a promising treatment against pre and post emergence damping-off and root rot diseases followed. Correlation of antifungal substances as alkaloids, tannins, coffeic acids and solubility in water are reasons explain the toxic effects of plant extracts (Qasem and Abou-blan, 1996). Our result on essential oils indicated that three essential oils (Anise, Thyme and Camphor) were fungitoxic. The complete inhibition of the growth of fungi species studied occurred at laboratory. The other 4 essential oils have no toxic effect against the studied fungi at three concentration. Anise oil was the most effective and fungitoxic oil that caused complete inhibition at $1.0 \%$ concentration of the three soil borne pathogens under study. Moreover, Thyme oil resulted in complete inhibition of $R$. solani at $1.0 \%$ and on $F$. oxysporum as well as $S$. rolfsii at $2 \%$ conc.. Camphor oil caused $62 \%$ inhibition on R.solani, and 47.8 inhibition on $F$. oxysporum and complete inhibition at $1.0 \%$ on $S$. rolfsii. These a highly fungitoxic oils showed a relationship between chemical structure and it's antifungal effect which might be due to the presence of monoterpenes hydrocarbons, $\alpha$ - terpinene and $P$ - cymene coffeic acids and tannins aliphatic aldehyde, phenolic - $\mathrm{oH}$ group and it can easily from hydrogen bond, with active sites of enzymes. These findings in agreement with Zambonelli et al. (1996); who mentioned that Thyme oil led to a complete inhibition of $R$. solani.

Continued research and development with natural products are needed to improve its efficacy through identification of more effective active agents, development of better formulations. Continued work with these types of materials and approaches, alone, and in combination with established control methods under field conditions, is warranted and necessary as we strive for more and better options for sustainable disease management for the future. 


\section{REFERENCES}

A.O.A.C., Association of official analytical chemists (1990). Official methods analysis of the association of official analytical chemistis. Washinton, 25. D.C., USA.

Abada K. A. (2003) Fungi causing damping-off and root-rot on sugarbeet and their biological control with Trichoderma harzianum. Agric Ecosyst Environ 51:333-337.

Abada, K. A. M. (1980) Studies on Sugarbeet Root-rot with Special Reference to Sclerotium rolfsii Sacc.. M.Sc. thesis Fac. Agric. Cairo Univ.

Abada, K. A. (1994)Fungi causing damping-off and root rot on sugar beet and their biological control with Trichodermm harzianum .Agriculture, Ecosystem and Environment,51(3):333-337.

Ata, A. A.; M.G. El-Samman; Maysa A. Moursy and M.H. Mostafa (2008). Inducing Resistance against Rust Disease of Sugar Beet by Certain Chemical Compounds. Egypt. J. Phytopathol., Vol. 36, No.1-2, pp. 113132.

Ayala-Garcia, J., G. B"uttner, H. Guti'erez, W. Heijbroek, P. loannides, M. Nihlgaard, M. Richard-Molard, L. Panella, V. Rossi, H. R"ossner, J.H.M. Schneider \& A. Wauters, 2001. Integrated control of Rhizoctonia root rot - First results of an I.I.R.B. trial series. In: Proceedings of the 64th Congress of the Institut International de Recherches Betteravi eres, pp 397-400. IIRB, Brussels.

Bateman DF, Beer SV (1965) Simultaneous production and synergistic action of oxalic acid and polygalacturonase during pathogenesis of Sclerotium rolfsii. Phytopathology 55:204-211

Buttner,G., B. Pfahler and B. Marlander (2004). Greenhouse and field techniques for testing sugar beet for resistance to Rhizoctonia rot and crown rot. Plant breeding, 123(2)158-166.

Carcia, R.P., and Lawas, M.V. (1990): Potential plant extract of Azolla fungal pathogens .Philippine Agricultural 73: $343-348$

Domsch, K.H.; Gams, W. and Traute-Heidi A. (1980). Compendium of Soil Fungi. Academic Press. A Subsidiary of Harcourt Brace Jovanovich Publishers, London. 859pp.

Duffus, J.E. \& E.G. Ruppel, 1993. Diseases. In: D.A. Cooke \& R.K. Scott (Eds.), The Sugar Beet Crop, pp 346-427. Chapman\&Hall, London.

El-kazzaz ,M.K; M.A .Hassan; M.M. Badr and K.E. Ghoniem (1999). Studies on sugar beet root rot disease in northern Nile Delta .J. Agric. Res.., Tanta Univ.,25(2):122-131.

El-Kholi, M. A. (1978). Studies on Root Rot of Sugarbeet in Egypt. M.Sc. thesis Fac. Agric. Ain-Shams Univ.

EL-Kholi, M. A. (1984). studies on fungal disease of sugar beet in A.R.E. Ph.D., thesis, Fac. Agric., Ain Shams Univ.,183pp.

El-shamy, Mona A.; F.A.. Fadil .;K.A .Tawfik. ;A.R .Sirry and M. M. El-zayat. (1985). Antifungal property of Garlic clove juice compared with fungicidal treatment against Fusarium wilt of watermelon .Egypt $J$ .phytopathology, 17(1)55-62.

Esh, A.M.H.E. (2000).studies on some sugar beet root diseases in Egypt. Fac. Agric. Zagazig .Univ., 287pp.

Fahim, M.M. M.A. Kararah ,A.A. El-Gharabawi and K.A.M. Abada (1981). Studies on fungi causing root rot of sugar beet with special reference to Sclerotium rolfsii .Egypt.J.Phytopatholgy.,13:1-2.

Gomez, K.A. and A.A. Gomez (1984). Statistical Procedures for Agricultural Research. John Wiley \& Sons, Inc. New York, U.S.A. 680pp. 
Gouda, M.I.M. (2001). Studies on some sugar beet root diseases .ph.D. thesis ,Fac .Agric .kafr Elshiekh univ.150pp.

Hammer, K.A.; C.F. Carson and T.V. Riley (1999). Antimicrobial activity of essential oils and other plant extracts. Journal of Applied Microbiology, $86,985-990$.

Janssen, A.M., J.J.C Scheffer and Baerheim Svendsen, A. (1987). Antimicrobial activity of essential oils: a 1976-86 literature review. Aspects of the test methods. Planta Medica 53, 395-398.

Johnson R T; J.T. Alexander; G.E. Rush and G.R. Hawkes (1971). Advances in Sugarbeet Production: Principles and Practices. lowa State Univ. Press, Ames.

Kessmann, H.; Stamb, T.; Hofmann, C.; Maetzke, T. and Herzog, J. (1994). Induction of systemic acquired disease resistance in plants by chemicals. Annu. Rev. Plant Pathol., 32: 439 - 459.

Khettabi N, Ezzahiri B, Louali L, Oihabi A (2001) Effect of fungicides and Trichoderma harzianum on sclerotia of Sclerotium rolfsii. Phytopathol Mediterr 40:143-148

Lawson,L.D.,G.wood and B.G.Hughus (1991). HPLC analysis of allicin and other thiosulfinates in garlic clove homogenates. Plant med.75:263270.

Luterbacher M.C., M.J.C. Asher1, W. Beyer, G. Mandolino, O.E. Scholten, L. Frese, E. Biancardi, P. Stevanato, W. Mechelke and O. Slyvchenko (2005). Sources of resistance to diseases of sugar beet in related Beta germplasm: II. Soil-borne diseases. Euphytica, 141: 49-63.

MC Ginnis, R.A. (1982). Beet sugar technology. 3 rd edn. Beet sugar development foundation for Collins, $855 \mathrm{pp}$.

Mosa,A.A.; ABD-EL-Sayed, W.M,; EL Kholli, M.M.A. (1996). Biological control of Rhizoctonia damping-off of sugar beet by Pseudomonas fluorescence .Arab universities journal of Agricultural sciences 5(2)433447.

Pandey, D. K., N. N. Tripathi, R. D. Tripathi, S. N. Dixit (1982). Fungitoxic and phytotoxic properties of essential oil of Hyplis .waveolens. Z. PflKrankh PfISchutz 89(6), 344-349.

Punja, Z. K. \& Damiani, A. (1996) Comparative growth, morphology, and physiology of three Sclerotium species. Mycologia 88: 694-706.

Qasem,j.R.andH.A.Abu-Blan. (1996). Fungicidal activity of some common weed extracts against different plant pathogenic fungi .J. Phytopathology 144:157-161.

Rizk, M. A. (1986). A survey on the Mycoflora-- with Emphasis on Pathogensassociated with Sugarbeet Cultivation in Saline Egyptian Soils. Ph.D. thesis Fac. Sci. Cairo Univ.

Rizki, Y. M., K. Fatima, I. Ahmed, B. Yasmin (1984); Studies on antifungal properties of indigenous plants from Karachi region. Part II. Pakistan J. Sci. Res. 32,608-611.

Ruppel, E. G., C. L. Schneider, R. J. Hecker, and G. J. Hogaboam, (1979) Creating epiphytotics of Rhizoctonia root rot and evaluation for resistance to Rhizoctonia solani in sugar beet field plots. Plant Dis. Report. 63, 518-522.

Schneider, C.L. \& E.D. Whitney, (1986). Rhizoctonia root and crown rot. In: E.D. Whitney \& J.E. Duffus (Eds.), Compendium of Beet Diseases and Insects, p. 21. American Phytopathological Society, St. Pauls, Minnesota.

Shekhawat, P. S., R. Prasada (1971). Antifungal properties of some plant extracts. I. Inhibition of spore germination. Indian Phytopathol. 24, 800802. 


\section{Abdalla, M.E. et al.}

Singh, R.K., and Dwivedi. (1990). Fungicidal properties of neem and blue gum against Sclerotium rolfsii .a root rot pathogen of barley .Acta Botanica indica 18;260-262.

Thompson, D. P. (1989): Fungitoxic activity of essential oil components on food storage fungi. Mycologia 81(1), 151-153.

Whitney E D and Duffus J E (1986). Compendium of beet diseases and insects. Am. Phytopath. Soc. St. Paul.

Zambonelli ,A.: Zechini,A. ,A .,Bianchi ,A.,and Albasini ,A., (1996). Effects of essential oils on phytopathogenic fungi in vitro. Journal of phytopathology 144:491-494.

Zedan.A.M. (1993). Antifungal properties of certain plant extracts with A special reference to the possibility of controlling onion white rot disease using Eucalyptus robusta leaves .Egypt .J.App.Sci.,8(12);574-589.

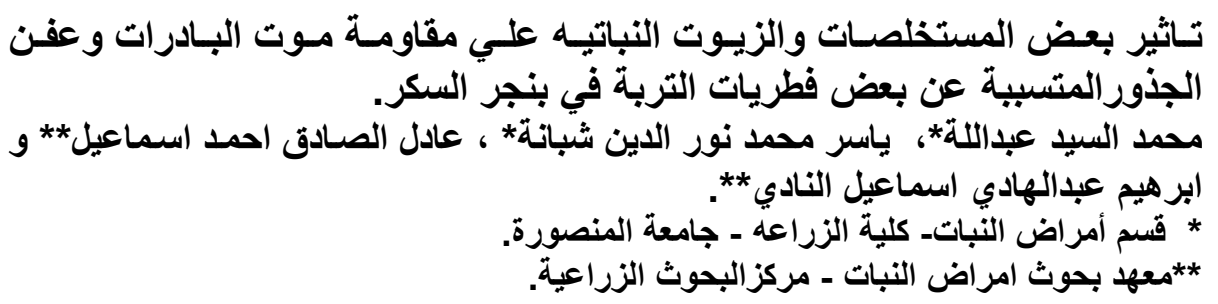

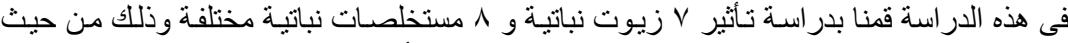

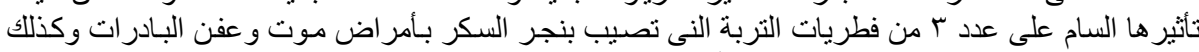

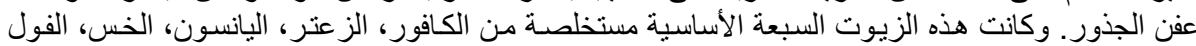

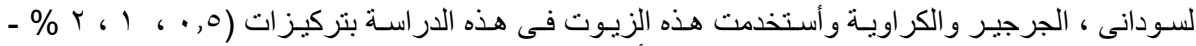

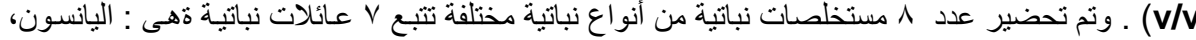

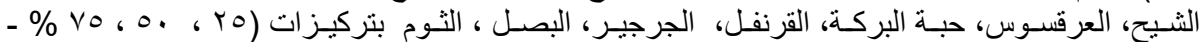

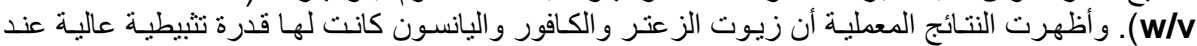

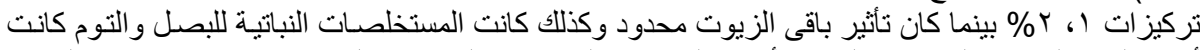

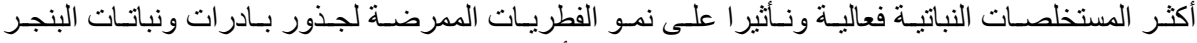

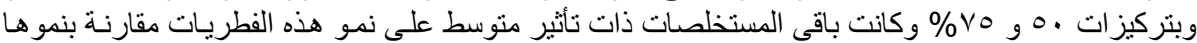

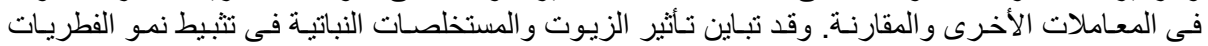

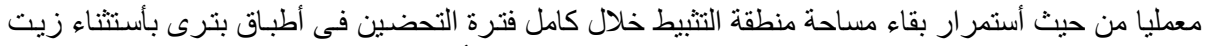

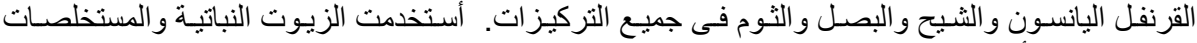

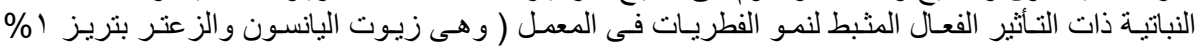

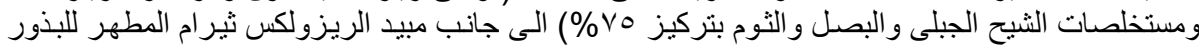

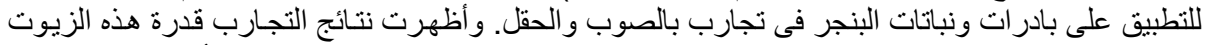

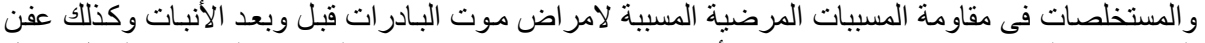

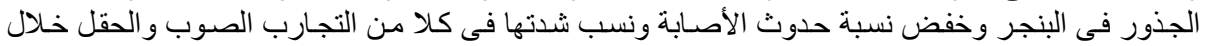

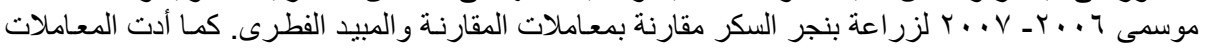

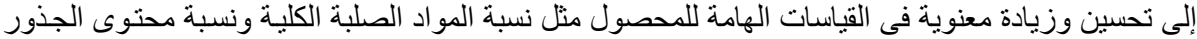

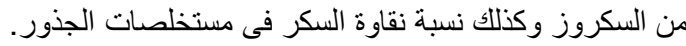
كلمات مفتاحية: بنجر السكر، فطريات التربة ، مستخلصات نبات التية، زيوت نبات نباتية أساسية. 